\title{
BIOGRAPHY OF HON. CHARLES JOHN ALFRED ERICSON.
}

\section{By Chari.es L. Dahlberg.}

In recording the life of Hon. C. J. A. Erieson, I have drawn freely from comments of the press, the views of some of those who knew him best, as expressed by them while he was yet living, as well as expressions ealled forth by his death, believing that by so doing a truer and clearer conception of his life and character may be obtained.

Charles John Alfred Erieson was born in Sodra VI parish, near Vimmerbi, province of Calmar, Sweden, on the 8th day of March, 1840. His father, Eric Nelson, was a farmer by occupation, and with his family eame to America in 1852, settling near Moline, Illinois, where he engaged in farming and fishing, both of which oceupations he had followed in Sweden. Later he removed to Webster county, Iowa.

The early education of Charles J. A. Erieson was obtained in the eommon schools of his native land, where he pursued his studies until twelve years of age, when he accompanied his parents to this country, and continued his education in the common schools of Rock Island county, Illinois. Although his attendance at school was very limited, the lack of knowledge in this respect was remarkably well supplied by his extensive reading, his study of human nature, and, in later years, his travels, all of which gave him a mind well stored, especially with reference to matters of business and the affairs of the world generally, in the time in which he lived. He once stated to a friend that one means he had used in aequiring information was the constant attempt to associate himself with those from whom he could learn, an example well worthy of emulation by all, for Mr. Erieson was not only able to tell what he knew, and to express it well, but he was also a good listener and listened with profit to himself. 


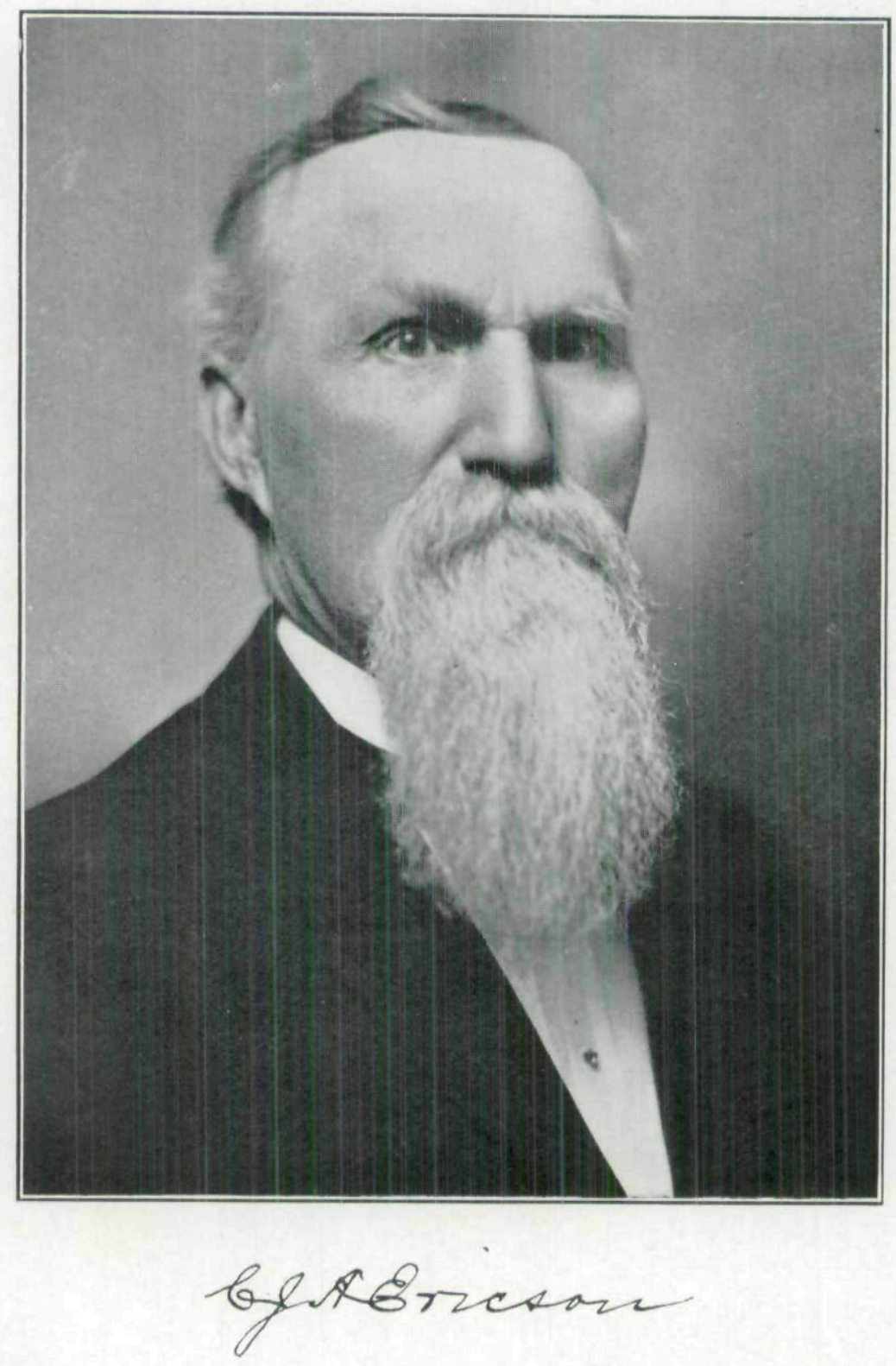


At the age of thirteen he began work for his elder brother upon a farm, and still later he assisted in running a flat-boat ferry across Rock River. The family then moved to Altona, Knox county, Illinois, where he worked in a general store for his two elder brothers. In the spring of 1859 he located in Boone county, at Mineral Ridge, where he opened a small store, having but little capital. He also engaged in buying and selling eattle and other live stock, and in both branches of his business he met with ereditable suceess.

Mr. Ericson was six feet two in height, his body erect, with no surplus flesh, weighing on an average two hundred pounds or a little over. He was an athlete of no mean ability, and in his younger days often accepted challenges to friendly contests of strength, in which he rarely failed to come off victor.

Mr. Ericson was twice married. In 1858 he wedded Miss Matilda Nelson, and to them were born two daughters, Alice and Lorena. In 1873 he was united in marriage with Miss Nellie Linderblood, who died in 1899.

Among Mr. Erickson's early experiences which he has related to his friends, was his first visit to Des Moines to buy goods, after locating at Mineral Ridge, driving across the country with team, the only mode of freighting in those days. He had very little ready money and on arrival at Des Moines selected only a small bill of goods. The wholesale merchant with whom he was dealing, impressed by his personality, told him to take what he wanted, pay down what he could and bring him money or exchange produce for the remainder when convenient. This was Mr. Erieson's initiation into a business in Boone county that grew ultimately into a large general merchandise store in the eity of Boone. It was the largest in the county, perhaps, at that time and laid the foundation for a business eareer that led not only to the aceumulation of a handsome fortune, but a competence that enabled him to do a wonderful amount of good to his own, the Swedish, people, which has certainly been greatly appreciated by them as well as those who are conversant with his life and methods.

His appreciation of humor, even at his own expense, is seen in an incident he sometimes referred to, which occurred 
in his early experience at Mineral Ridge. At a certain season of the year it was his custom to buy cattle, prineipally what is now called "butcher stock." His first purchase of a drove was at a uniform price per head for an animal, large or small. His surprise can be imagined when in Iowa City, where he had to go for a market, he learned that cattle were bought by weight, and that an animal weighing seven hundred pounds was worth less than one of twelve hundred. Of course one lesson was sufficient.

In 1870 he purchased the general store of Jackson Orr, in Boone, and for five years carried on a general merchandise business. In 1872 he assisted in the organization of the First National Bank of Boone, and was elected its vice-president. In 1875, he closed out his mereantile interests and became cashier of the First National Bank, which surrendered its charter and was reorganized as the City Bank of Boone in 1878. On the death of Mr. Frank Champlin, Mr. Erieson became president of this bank, which position he held at the time of his death.

In all his business undertakings he seemed possessed of those traits of character which always lead to success, of which no better description ean be given than to quote the last paragraph of an article which he himself wrote for the Boone News Republican of date May 23, 1907, under the title of "Memories of a Swedish Immigrant of 1852,'” as follows:

What little success I have attained I attribute to three things; first, honest and fair dealing with every man; second, refraining from speculations and investments in outside enterprises, but attending strictly to my own business; and, third, making my word as good as my bond.

In 1863 he became a Mason, holding membership in Mount Olive Lodge, No. 79, A. F. \& A. M. He was also a member of Tuscan Chapter, R. A. M.; Excalibur Commandery, No. $13, \mathrm{~K}$. T.; and held all the principal offices in these organizations, serving as treasurer of the Commandery there from the time of his first residence in Boone until his death. 
Throughout his mature life he took a deep interest in polities, and for ten years, while still a young man, filled the position of postmaster of Mineral Ridge. He also served as road supervisor, school director, school treasurer, and township clerk. He was also alderman of Boone, city treasurer for several terms, and president and treasurer of the school board. He was an active member of the Presbyterian church, and took great interest in religious work, being treasurer and trustee for some thirty years.

In 1871 he was elected a member of the Fourteenth General Assembly of Iowa, on the Republican ticket, his opponent being Judge M. K. Ramsey. He served during the regular session and during an extra session, which was called in 1873 to revise the Code, again rendering service in the revision of the Code while a member of the Senate of 1897.

In 1895 he was elected to the Senate, where he served in the Twenty-sixth, Twenty-sixth extra, Twenty-seventh, Thirtieth, Thirty-first, Thirty-second and Thirty-second extra General Assemblies.

During his terms of office as state senator, his ability as a financier was recognized in his appointment as a member of the Committee on Ways and Means at every session, and chairman of the Committee on Claims in the Twenty-sixth, Twentysixth extra, and Twenty-seventh General Assemblies. In the Thirtieth and Thirty-first General Assemblies, he was chairman of the Committee on Public Libraries, and in the Thirtysecond General Assembly was chairman of Constitutional Amendments and Suffrage. During the last three sessions he served on committees on Banks.

While serving in the Senate in the Twenty-sixth General Assembly he introduced a bill which passed both houses, whereby corporations are taxed $\$ 25.00$ for the first thousand, and an additional dollar for each one thousand thereafter; not, however, to exceed $\$ 350.00$ for any one corporation. This was in lieu of the nominal fee theretofore charged.

In the Thirty-second General Assembly he also introduced and secured its passage through the Senate, a bill requiring 
annual fees to be paid to the Secretary of State by all corporations doing business within the State.

In the Twenty-seventh General Assembly he introduced a bill redueing the interest on state warrants from six to five per cent.

There were three things, however, that seemed uppermost in his mind; viz., the Historical Department, Public Libraries, and the Agricultural College. During the last three sessions in which he served, out of thirty-three bills introduced by him, eleven were in the interests of the Historical Department and Public Libraries, and seven in the interest of the Agricultural College; and much of the success of these departments of státe is due to his untiring efforts in their behalf. Doubtless his interest in the Historical Department was intensified by his friendship for and high esteem of Hon. Charles Aldrich, its first eurator, who, like himself, was imbued with the idea of building and establishing for the benefit of future generations as well as for the present. His work in the interest of the State Agricultural College was recognized by all connected with that school.

Aside from his interest in these departments, he rendered valuable service and was largely instrumental in the passage of the bill for taxing corporations, which has added largely to the income of the State of late years. He introduced a bill in the interest of good roads and might be considered one of the pioneers in this work which is now being so strongly agitated. One thing that showed the love of nature strongly marked in his character was the introduction of bills at two different times in the interest of the feathered songsters of the forest, their nests and eggs.

The appreciation of Senator Erieson and his work in our State Senate has been so well set forth by two of his colleagues, that I herewith submit their own words:

W. C. HAYWARD, Secretary of State: During three of the five sessions that I served in the State Senate, Hon. C. J. A. Ericson was a member of that body. We were both members of the Ways and Means Committee, and both lived during the session at the 
Savery Hotel, and I then had an opportunity of becoming quite well acquainted with him.

He was a large man in every way, physically and intellectually. He was of fine appearance, and of the most kindly disposition. He took a special interest in educational affairs and was a firm and steadfast friend of our educational institutions. He was a careful and considerate man, one of whom it could be said that he was "safe and sane"; at the same time he was in every sense of the word "progressive," and an advocate and supporter of all progressive measures along reasonable lines.

$\mathrm{He}$ was mild and pleasant in manner, but, at the same time, firm and unyielding in support of what he deemed to be right.

A splendid, big, strong man. It was a distinct loss to the State he loved so well when he passed away.

WARREN Garst: My people moved to Boone in June of 1866 . Almost from the first the name of Mr. Erieson became a household word on account of the prominent position he held in that community. It was not strange, therefore, when I became associated with him in a legislative way I should remember the earlier impressions I had received in the community in which we then lived. I found Senator Erieson to be a powerful force in all remedial legislation; always throwing his influence and vote in any cause he thought to be for the betterment of society. He was especially active and exceedingly fortunate in formulating plans to increase the revenues of the State from sources that would not be burdensome and at the same time would be greatly remunerative. As I remember it, under the old law any incorporation organizing in Iowa was required to pay a mere nominal fee into the coffers of the State. Senator Ericson introduced a bill that changed this and we now have had instances where very large corporations have paid many thousands of dollars in single fees.

He also introduced and secured its passage through the Senate, a bill to tax corporations through an annual fee. Senator Ericson figured that if his bill became a law it would add to the revenues of the State from $\$ 150,000.00$ to $\$ 250,000.00$ annually.

It is not my purpose to go into the discussion of this proposition as to its justice or fairness, but I was then and am now in thorough sympathy and accord with Senator Ericson's position.

While Senator Ericson was seeking every way to secure additional revenues for the State, through any of the then established means, he was liberal with suggestions as to distribution. He was anxious to see the great agricultural school at Ames become 
one of the leading institutions of this character, not only in this country, but in the world. His success along this line is best attested by what this great institution is doing and is.

He always had a great interest in the history of the State, and perhaps it is more due to him and his untiring energy than to that of any other man that we have the magnificent Historical Building, which is an asset of state-wide importance, for it seems to me that no man, woman or child can visit this elegant structure without having a greater pride and a greater love for this great State.

I have no disposition to go into detail as to Senator Ericson's legislative experience. I am indeed glad to have the opportunity to say to the people of Iowa that, while there have been men who have perhaps been more conspicuous, there has been no man who has done more along material and ethical lines than the Senator from Boone.

Following is an editorial from the ANNALs of Iowa, a few years previous to his death:

It is seldom, indeed, that an immigrant from a foreign landunable to speak a word of our language-rises from the laboring class to such an enviable position in his new home as that so fittingly occupied by Senator Ericson. His life has been one of business success and filled with useful public labors. He has given timely aid to poor and struggling young people, especially in their efforts to secure thorough education. He has for many years been a strong supporter of the Augustana Lutheran College at Rock Island, Illinois. He is a member of the committee which has labored with much success in securing permanent endowments for the institution. It has been largely due to his efforts that valuable real estate has been acquired for the benefit of the college. In this work he has been a liberal giver. He erected, entirely at his own cost, the beautiful and commodious public library building in the city of Boone. He served one term (1872, including the extra session in 1873) in the Iowa House of Representatives, and is now serving his ninth year in the State Senate. Schools, public libraries, and the Historical Department, have always found an intelligent, progressive and influential friend in Senator Ericson. His life is a record of sterling honesty which is absolutely unimpeachable.

The Iowa Library Quarterly for July, August and September, 1910, contains this recognition of his service:

He was deeply interested in the work of the Iowa Library Association, having served as Vice-President of that body, and 
repeatedly on Legislative committees, attending the annual meetings regularly. His presence will be greatly missed, as well as his advice and counsel.

Senator Ericson was a man of gentle character, with strong friendships and deep convictions. His place is not likely to be filled again in the library circles of the State or in the hearts of those whose friendship he had gained.

At a cost of $\$ 10,700.00$ he built the handsome library in his home city which is known as the Erieson Library. In 1901, by request of the Board of Trustees of the Historical Department of Iowa at Des Moines, through the Hon. Charles Aldrich, curator, he furnished a fine Carrara marble bust of himself made by a noted artist in Florence, Italy, which was presented to, and now occupies a place in the Iowa Hall of History. Possibly to his limited opportunity to attend school may be attributed his love for books, the study of which more largely than he knew supplied a deficiency in his early education. Possessed of a broad and generous nature, he wished others to share with him the benefits derived from good books.

Judge Horace E. Deemer evidently understood this phase of Senator Ericson's character, as shown by the following extracts from his address at the dedication of the Erieson Li. brary, October 2, 1901:

It is a proud day for Boone, and a pleasant one, I know, for the generous donor who has built a monument to himself which will outlive any mere creation of the builder's art, chiseled simply to perpetuate the memory of a name.

Within the past few years at least three generous and loyal men within the boundaries of this State have made large contributions for the building and founding of public libraries; and it is my deliberate judgment that they have made the best possible use of their money. That the communities to which they have been given fully appreciate the generosity, I have no shadow of doubt; and that the people of this little eity of Boone are filled with gratitude to their honored fellow citizen, Senator Ericson, is so plainly evident that it scarcely needs mention. I am not so sure, however, that any of these men fully appreciate the value and the full significance of their generosity.

In this building rich and poor alike may meet the best and greatest thinkers of the age. Wealth gives no advantage, and 
social position counts for nothing. No matter how poor the boy or girl, no matter how thinly clad, no matter though the prosperous of their own town or time will not recognize them on the street, no matter though they are excluded from the so-called best society, here they shall not pine for companionship or society. Here Milton will tell of Paradise, Shakespeare open all the flood gates of the imagination, Franklin give forth his practical advice, Bryant sing of nature's beauties, Darwin and Huxley elucidate their theories, Proctor search the skies and Thackeray forget his snobbery. Here one may select his own associates from among the greatest thinkers and actors and writers the world has ever known. He may meet the most eminent statesmen and scientists, poets and philosophers of all time. As said by another, "He that loveth a book will never want a faithful friend, a wholesome counsellor, a cheerful companion, and an effectual comforter." But, better than all, here, perhaps, may some spark set fire the smouldering fumes of genius, and a flame go forth that will illuminate for all time the pages of our Western literature.

Senator Erieson's ambition to go to his native land as minister from this country, led him to enter the field as a candidate for that appointment. The strength of his candidacy because of his fitness, would undoubtedly have secured him that appointment, but for what is known as the "unwritten law" that has always existed, which is that it is regarded as against public policy to appoint any one minister to the country of their nativity.

In polities as well as in business, Senator Erieson always had high ideals which he lived up to. A notable instance of this is, when urged by many of his friends near the close of his first service as State Senator to become a candidate for renomination, he positively declined because of a tacit understanding between the two counties of Story and Boone that they should alternate in sending a representative to the State Senate from that district, composed of those two counties. No argument could induce him to violate that compact, and his successor was chosen from Story county.

In July, 1903, he was appointed chairman of the Scandinavian Relief Committee to assist the famine stricken districts of Northern Scandinavia, which committee was suceess- 
ful in raising large amounts for that purpose, his services in this respect being recognized in a letter from Governor A. B. Cummins, in the following language:

The success of the plan must be credited, in a large measure, to your patriotic and intelligent labors. For this work, and in behalf of suffering humanity, I thank you.

In 1904 Senator Erieson was appointed a member of the Iowa Commission for the Louisiana Purchase Centennial Exposition. As a member of such Commission he had charge of the dairy and apiary department, and his business skill and judgment were shown to a remarkable degree, as it proved to be one of the best managed departments, especially with reference to its finances, of the entire exhibition.

On the fiftieth anniversary of Senator Ericson's settlement in Boone county, at a banquent given to his friends in the Masonic Temple at Boone, the love and esteem in which he was held by his many friends, especially those who knew him best, was brought out in toast after toast. The following extract from one prepared by Mr. C. S. Mason, who had known Senator Erieson for so many years, pays him one of the highest compliments that could be paid to a friend, and his knowledge of the man and his character and manner of life was such as to enable him to draw a most faithful picture of his worth and work:

Men often criticise; sometimes they flatter. Avoiding both, 'tis my desire to speak the truth, for he who even roughly paints a picture, using brush, or pen, or lips, should first of all paint true. In such a spirit I approach the pleasing task I have undertaken, and, happily, in this ease there is little incentive to over-state the facts or over-paint the picture, for in the life and character and record of our friend, the truth is an all-sufficient eulogy. Should I say he is a king of finance, you would not believe me; should I report him possessing, far above his fellows, the qualities of great statesmanship, I would not believe myself; or, should I picture him possessed of genius, he would perhaps laugh me to scorn; but when I say that in finance he is wise and just and withal merciful, I am saying that which I suppose you now believe; and when I say that he has brought to the performance of his public duties the same test of high manhood and good intentions that 
has guided him in business affairs, I am saying that which I believe will meet the approval of his conscience and win for me the smile of approbation.

Is this man wise? I know of no better test than to apply the record. Born in a humble home across the sea, he left when young the confines of the old world that he might stand upon the shores of the new, where, looking out upon a splendid age, in a splendid republic, he might search for a place where he could struggle and perhaps achieve. Fate or some subtle influence that we cannot explain, led him to locate near this vicinity, and for fifty years he has gone in and out among, and been one of the people of this community. I think it fair to estimate that in all those years he has averaged ten business transactions daily; one hundred and fifty thousand business transactions with his neighbors and the people among whom he lives, and if about a single one there is a taint, or even a suspicion of dishonesty, then has my information been at fault. Surely such a business record as this is one of which he or any man may well be proud. Not only has he gained high reputation for business honesty, but in a larger way he has achieved success in that he has succeeded first in winning the kind regards, and in more recent years, the loving esteem of a great majority of the better class of people among whom he lives. To such an extent is this true, that the people have delighted to place upon him political honors and have asked of him the performance of important political duties. Not only has he gained a high reputation for business honesty, and gained the respect of the people in all the other matters of which I speak, but during these years he has been gathering together in an enterprising way and without in the least injuring others, that which we believe to be a sufficient competency which has enabled him not only to meet generously the many, many requirements made upon men of reasonable wealth, but has enabled him in more recent years to do those things which he hopes, and which we believe, will redound to the benefit of this and other communities for many years to come. Surely such a record as I have briefly, and I trust, truthfully described, needs little comment.

Is our friend kind beyond the average man? Upon this point I have testimony, and first I will place upon the stand yourselves, and ask if, in the few or many years you have known him, there has not been some one, perhaps many, occasions, when, by kind words or some kindly act, he has won the affection of your heart and gained the confidence of your understanding. There are many witnesses I should like to call whom I cannot secure, for many of them are resting under the infirmities of old age and living quietly in their declining years in the homes and upon the farms 
that the kindness of our friend has helped to secure, while many more have finished their work and made their record and have gone home to their reward and rest within their graves in different portions of this country; and, as I cannot present to you their testimony, permit me briefly to call attention to it second hand. First and last and at different times, and not by design, but accidentally or in a casual way, I have heard from the lips of at least twenty different men, the story of the help they have received from our kind friend. Some have spoken of these obligations without any show of sentiment, while others have shown upon their faces that there was within them the spirit of gratitude. If, in a casual way and without design, I have heard from the lips of twenty men of the assistance they have received from our kind friend, is it not fair to presume that there are in this vicinity, living and dead, hundreds who, could they speak to us, would add to the volume of our testimony? Permit me to take the stand myself. Some years ago our country was swept by a financial tornado, the worst financial panic I have ever known; great business houses tottered and some fell; and, while the general business interests of the country were to some extent palsied, the fierceness of the storm centered upon those engaged in the banking business, for everywhere men seemed to have lost confidence in banks and in each other; hundreds of millions of dollars of deposits were drawn from banks and hid away in stockings and in safety deposit vaults, and everywhere the depositors in banks were watching for the least sign of danger, that they might quickly pounce upon the banks that held their deposits and bring to them temporary disaster, if not destruction. At such a time as this, the business firm of which I am a member needed funds. I spoke to a banker of this town about it, and quickly, almost fiercely, got his refusal. A little later I saw our friend and spoke briefly of our needs and said, "I guess I will have to ask you for some money." He said, "How much?" I replied that temporarily two or three thousand dollars would answer. Drawing a long breath that was mighty near a sigh, and speaking in a tone of almost pleading, he said, "Keep it as near two thousand as you can." Any man can assist another when it is in his regular line of business and for his profit to do so. There are here and there some, perhaps in the aggregate many, who, upon some occasion, will assist their fellow men even though the element of profit does not attach to the transaction; but there are mighty few men in all the world, nor have there ever been, nor will there be in all the years to come those who, in time of storm and stress and danger, will weaken their own position that they may extend a helping hand to a business acquaintance. I presume the trans- 
action I speak of was forgotten by our friend within an hour, for he had other important matters on his mind; but I did not so soon forget, nor have I yet forgotten, nor will I forget, during all the years that are spared me, for I thought then, and it seems to me now, it was a bright spot in the midst of surrounding gloom, and an oasis in the desert of human selfishness.

I have a grandson who bears my name. I hope through him the name may be continued; yes, in a broader sense, I hope through him the family name I bear, and which is now held by so few living representatives, may be carried into future generations where possibly it may become an honored name among the people; so I feel for that boy great interest, and I would make for him great sacrifices, if thereby I could surround him with the influence and furnish him that training which would secure for him in future years the qualities of good citizenship, and I have often thought, and think today, that if, among all the men I know or have ever known, East or West, I was obliged to select the one man of all others whose traits of character, of mind and heart and brain, and whose every quality, good and bad, the boy must emulate and at last attain to, my choice would fall on our kind friend. Surely no higher words of praise than that can I bestow.

A pebble tossed upon the placid surface of a lake creates a ripple that broadens, widens, extends until it is said there is a ripple on the other shore. A man's good deeds live after him, broadening, widening, extending, losing perhaps their identity, but working in harmony with other good influences-working on and on and on, and who shall say that these good influences will not continue to do their office in the world until the end of time?

Our friend has led a clean and manly and useful life, worthy the emulation of young men; and, in more recent years, he has been able to set in motion good influences which he hopes, and we believe, will work for the civilization and the improvement of mankind when he shall have passed away; and who shall say that the good influences he hath thus set in motion will not continue in some way, working on and on until the records of time shall cease?

Senator Ericson's death called forth many comments on his life; such as:

Boone News-Republican: He cared for his fellow men sincerely and was always doing something for them. But he was not simply good, he was forceful and energetic. A wonderful dynamic energy held sway under a calm and quiet exterior. 
His peculiar claim to genius, however, lay in his ability to succeed in whatever he undertook.

Loyal to his friends and to his eity, he never had a thought that his large and growing competence made any chasm between him and his poorest acquaintance. He was a man to all men, honorable, considerate and cordial.

In another article by the same paper, entitled "A Christian Viking"':

History records that his Scandinavian progenitors gave birth to the dynasty that has ruled Russia for many generations; their blood also percolates in the veins of Germany's emperor, and even in the lines of Queen Victoria, down to the young king of Britain, George V. How remarkable that in the course of human transformation throughout the ages, this bold, warlike, and often cruel, nation of men, should produce a man, who, in the walks of official and commercial life, should set an example of honor and success far above all the warlike achievements of his race and its early history.

The Register and Leader, commenting on his record, said:

In his business career Senator Ericson demonstrated what a poor boy, with no capital but his hands, his head and his strong courage, can achieve in this great land of opportunity. In his career as a citizen he demonstrated to what heights of loyalty and devotion to an adopted nation and commonwealth a foreign born youth may attain. In business he won every success and a bountiful share of this world's goods; in public life he was accorded the very highest distinction by fellow citizens year after year. He was a true custodian of the wealth that came into his hands, and no man in Iowa ever gave more generously and wisely of his means for the promotion of the happiness and welfare of the people. $\mathrm{He}$ was true to every official trust imposed in him, and he rendered his State and his country notable service as a public servant. He was true to every obligation as neighbor and friend, and helpful always to those about him.

In a letter to his daughter Lorena from Rev. Emil Benson, pastor of the Swedish Lutheran Church, Rochester, N. Y.one of the many young men in whom he had taken an interest -we find the following:

What I am and the position I now hold, I owe to the kindness and generosity of your departed father, the respected senator, who gave me the educational start. 
His former pastor, Rev. Scott W. Smith, of Cedar Rapids wrote as follows:

I have always honored him as a lover of our Saviour and a friend of man, and have always rejoiced when word came of some new benefaction which his generosity had provided in the way of school and library endowment; and his memory will always be one of my precious possessions. He was a great help and inspiration to me in my work-never obtrusive with counsel or critical in his judgments, but quietly helpful in every undertaking for the advancement of the work of our church.

The esteem in which Senator Erieson was held by his associates in travel during the last four months of his life, is evidenced by the following extracts from letters received by his daughter, Lorena Erieson, after his death, and is voiced, I am sure, by all who knew him:

PAUL S. JUNKIn, Creston, Iowa: The state of Iowa suffered a great loss in the death of Senator Erickson. The Iowa people on the "Cleveland" were charmed by his simplicity and sincerity, and impressed by his ability, and made friends with everyone because of his sterling worth. We all felt a personal loss in his death.

REv. D. E. Lorenz, New York: I merely want to add my testimony to the fact of the high esteem in which he was held by everyone on the "cruise." He spoke several times to our travelers' club held on shipboard. I, personally, had every reason to admire and respect him, and the news of his death came to me as a real sorrow. I am sure it is a noble legacy to leave behind a life so useful to his country.

Mrs. Catherine M. KFeler, Rockford, mlinois: He contrasted the present voyage with its luxury to the one he had taken when he first came over; also described most entertainingly his audience with the King of Sweden. We surely are not justified in closing our doors to the foreigner who may prove as valuable and loyal an American citizen as your father. That he was one of God's noblemen, his will indicates.

Mrs. M. Jexnie Hodgson, Chicago: I consider him one of the most intellectual men on our cruise. We all esteemed him most highly, and said "goodbye" to him with sincere regret. He talked to me many times about you, and what he had purchased for "my daughter," as he so loved to call you. "A Christian Viking"what an appropriate name! 
Senator Ericson's cherished desire to add to his extended travels the cruise around the world, referred to in the above extracts, was gratified, when, on July 30, 1910, he reached his home in Boone, having left the January previous. Taken suddenly ill the evening of August 2d, three days following his return, in spite of medical aid, he died Sunday morning, August 7, 1910. So closed the career of one whose Christian character has made the world better; one who enjoyed the esteem and love of all who knew him, and of whom it can be said, as some one has so beautifully expressed it:

"To look into some eyes teaches us faith-

They are so true;

The sound of some voices lessens pain

Which is life's due;

The touch of some hands helps us live

Our whole lives through." 
Copyright of Annals of Iowa is the property of State of Iowa, by \& through the State Historical Society of Iowa and its content may not be copied or emailed to multiple sites or posted to a listserv without the copyright holder's express written permission. However, users may print, download, or email articles for individual use. 